\title{
Establishing the Roots of Community Service-Learning in Canada: Advocating for a Community First Approach
}

\author{
Wendy Aujla and Zane Hamm
}

\begin{abstract}
This article explores the roots of the Canadian community service-learning (CSL) movement through a comparative discussion of service-learning in Canada and the United States. The article provides a brief overview of CSL's historical foundations in both countries, addressing especially how differences in CSL funding infrastructure have distinctly shaped the movement in each country. While national funding bodies and nation-wide institutionalization remain central to CSL in the U.S., Canada's CSL efforts have predominantly been shaped by the efforts of private foundations and grassroots community agents. This essay analyzes the obstacles and problems currently within Canadian CSL, but also provides recommendations around documentation, sustainability, and the future of CSL in Canada, including the recommendation to maintain a community first approach in Canadian CSL. As it considers how the influence of the United States continues to shape CSL in Canada, and how the two national movements remain distinct from one another, we hope this examination will contribute an historical perspective to scholarship on Canadian CSL and will offer entry points to engage in critical conversations on the emergence of the field.
\end{abstract}

KEYWORDS community service-learning/service-learning, community engagement, community, Canada, United States

Community service-learning (CSL) in Canada began in the mid-1990s and grew throughout the 2000s, but despite some previous attempts to examine the field in this country, literature that explicitly explores the unique and growing Canadian context is limited. As Taylor and her colleagues (2015) highlight, in order to guide CSL programs in this country, specifically Canadian research and knowledge is required. Understanding the history and theoretical foundations of CSL is also integral, as these foundations inform pedagogical approaches used in CSL contexts and they impact the direction of CSL courses and programs. Although CSL in Canada has been influenced by the earlier development of service-learning (SL) in the United States, which began in the mid-1960s (Taylor et al., 2015), there are differences between the two national contexts, including geography and population density, funding and infrastructure, and underlying values and aims. In this paper, we examine how the servicelearning movements have been differently shaped in Canada and the United States in order to capture the distinctiveness of Canadian CSL. 
We argue that the uniqueness of Canadian CSL is rooted in its dispersal over a large territory with a relatively small and regionally distinct population; in its initial, catalyst funding through a philanthropic organization, the J.W. McConnell Family Foundation, rather than through government; and in its prioritization of local community concerns over nationalism, character education, or citizenship as pedagogical drivers, all of which have been more predominant concerns in the U.S. Our paper points toward the Canadian movement as locally specific, variable, and grassroots in structure. In contrast to CSL in the United States, which developed via a more balanced orchestration of private and public forces, and which has become more standardized given that CSL is now institutionalized and funded at the national level, private foundations were especially critical to CSL's establishment in Canada, and this history continues to shape how Canadian CSL functions today. To advance this argument, we first define service-learning and provide an overview of its history, funding, and infrastructure in the U.S. Next, we provide an outline and analysis of CSL in Canada. We discuss the role of the Canadian Alliance for Community Service-Learning (CACSL) in directing CSL movements in Canada and examine issues of funding, evaluation, and research. Throughout, we provide practical recommendations to sustain the Canadian field, building on Taylor et al.'s (2015) question: "what institutional structures and supports are necessary for CSL to flourish?" (p. 2). As part of these recommendations, we advocate for a Canadian approach to CSL that emphasizes the roles of community partners and students as co-educators and scholars who, together with faculty and post-secondary staff, are building a body of knowledge that is grounded in both theory and practice. CSL in Canada needs to prioritize long-term and sustainable relationships between partners who support civic engagement at the community and institutional level (Chambers, 2009; Gemmel and Clayton, 2009; Smith, 2010).

\section{Defining the Terms: Service-Learning and Community Service-Learning}

Definitions of service-learning and community service-learning are contested (Giles, 2008; Mooney and Edwards, 2001; Saltmarsh, 1996). Kendall (1990) observes that approximately 147 different terms have been used; in addition to "service-learning," the terms "public service," "community service," "experiential learning," "study-service connections," "social action," "civic education," and "action research" are often used interchangeably (Lena, 1995, p. 109). No one universal definition has emerged, despite Sigmon's (1994) widely-used typology, which distinguishes service-learning programs "from other approaches to experiential education by their intention to equally benefit the provider and the recipient of the service as well as to focus on both the service being provided and the learning" (Furco, 1996, p. 12). We contend that SL and CSL are different from other practice-based or community-based learning-for example, internships, co-op placements, or community activities that enhance course content. As Bringle and Hatcher (1996) explain, other forms of experiential learning and "the learning objectives of these activities typically focus only on extending a student's professional skills and do not emphasize to the student, either explicitly or tacitly, the importance of service within the community and lessons of civic responsibility" (p. 222).

Even though both "service-learning" and "community service-learning" operate as terms 
in Canada and the United States, "service-learning" is more commonly used in the U.S., whereas the term "community" is often added in Canada. Smith (2010) suggests that the Canadian terminology "deemphasizes the problematic word 'service" (p. 12), which, because it invokes the categories of "server" and "served," can be seen to terminologically enshrine unequal power relations between providers and recipients of "service" activities (Cameron, 2010; Giles, 2008; Himley, 2004; Mooney and Edwards 2001; Saltmarsh, 1996; Smith, 2010). As Smith (2010) further explains, CSL practitioners and institutions in Canada are often committed to community-building endeavors that extend beyond campus-community partnerships; higher education is not the essential component of Canadian CSL: "The frame or context is the whole community, and universities are only part of the community" (p. 9). Margo Fryer, former Director of the Learning Exchange at the University of British Columbia (UBC) and a founder of CSL in Canada, confirms that a strong commitment to community was at the heart of the vision for community-engaged learning and research that set the stage for CSL in Canada. ${ }^{1}$

Given the differences in language used to describe the field, we use the terms CSL and SL to signal our use of either Canadian or U.S. literature, respectively. However, like Smith (2010), we recognize that not all Canadian universities (e.g., the University of Manitoba or Brock University) or scholars, such as Chambers (2009), place the word "community" before service-learning. Regardless of the term used (SL or CSL), this is a pedagogical approach in which students are challenged to think critically about and apply their classroom experiences to community work done where they study and live (Bringle and Hatcher, 1996; Butin, 2007b; Gemmel and Clayton, 2009; Morton, 1995). Certainly, a feature shared by both terms is the hyphen between "service" and "learning," which signals that the two are not separate activities (Hoppe, 2004). Flecky (2011) notes that "the hyphen between service and learning is purposeful; it denotes a balance between the service and learning outcomes resulting from the partnership experience" (p. 2). We would add that service and learning coincide and that the hyphen identifies how service combined with learning allows for transformative experiences.

\section{Brief Overview of Service-Learning in the United States Historical and theoretical foundations}

Flecky (2011) traces the roots of SL in the U.S. to social-reform movements of the late 1800s and the establishment of land grant colleges in the 1900s, which "focused on the needs of the local farming communities" (p. 6; see also Smith, 2010). As Bringle and Hatcher observe (1996), American universities "have a tradition of serving their communities by strengthening the economic development of the region, addressing educational and health needs of the community, and contributing to the cultural life of the community" (p. 221). Universities are seen as being responsible for making their resources available to the larger community (Bringle and Hatcher, 1996), as well as "preparing students for productive citizenship" (Furco, 2010, p. 375). Indeed, one of the key goals of higher education in the U.S. is to produce educated

\footnotetext{
${ }^{1}$ Fryer's experience and the history of the Learning Exchange is shared in "The Call" (n.d.).
} 
and socially responsible or "good" citizens who can serve the nation and community (Boyer, 1996; Flecky, 2011; Lena, 1995), although what exactly "good" citizenship entails is too often undertheorized in literature and practice (Kahne and Westheimer, 1996).

In the 1960s and 1970s, criticisms emerged about the failure of universities in the U.S. to respond to social issues and encourage responsible citizenship in a democratic system (Boyer, 1996; Butin, 2010; Ward, 2003). Service-learning began during this time as "an attempt to undermine the taken-for-granted assumptions of an academy seemingly out of touch with its sense of purpose and unreflective about its own pedagogical practices" (Butin, 2010, p. xv). "One of the guiding themes," Taylor et al. (2015) add, "was the perceived need for students to get out and connect with the social realities of the real world" (p. 8). Internships were the primary form of service-learning throughout the 1970s: the federal government "invested approximately $\$ 6$ million annually in service learning programs, funding full-year, full-credit [internship] opportunities for students to engage in anti-poverty work in their communities (Lounsbury \& Pollack, 2001)" (Taylor et al., 2015, p. 8).

Service-learning was formally recognized as such in the 1980s (Taylor et al., 2015), followed by a period of "phenomenal growth" in the 1990s (Flecky, 2011, p. 6). During the 90s, the public was concerned with the "national obesity epidemic, high citizen apathy, increased religious and ethnic conflicts, rising crime rates, soaring student drop-out (or early leaver) rates, among other social issues," and the role of higher education in addressing these societal problems (Furco, 2010, p. 376). These concerns sparked discussions about the value of "social capital" - that is, the importance of social networks and reciprocal relationships of trust between universities and communities - in addressing societal issues (see Putnam, 1995; Serino, Marciano, Scardigno \& Manuti, 2012). In response, there was a call to reform higher education and renew its "commitment to community service" by combining learning and service to make a unique contribution to academic curricula (Lena, 1995, p. 108). Servicelearning thus became a strategy for curricular reform, with perceived "curricular irrelevance and the desire to create meaningful undergraduate experience (Kezar \& Roads, 2001)" as part of what drove the agenda (Taylor et al., 2015, p. 8). In this milieu, the dominant form of SL shifted to the "service-learning course, a credit-bearing academic course with a typical syllabus...along with a related community service component” (Taylor et al., 2015, p. 8), which continues as a prominent form of service-learning today.

Also in the 1990s, scholar Ernest Boyer called for U.S. higher education to once again reconsider the role of education to create responsible citizens (Boyer, 1996; Bringle and Hatcher, 1996; Ward, 2003). Commonly cited as one of the "founding fathers" of service-learning, Boyer (1996) was hopeful that higher education could assist with social, civic, economic, and moral problems through the scholarship of engagement, a term he coined. In his words, "the term engagement is used as a response to a general uneasiness many in higher education are feeling about the nexus of higher education's past, present, and future and how this composite history plays a role in society" (as cited in Ward, 2003, p. 12). Arguing that academics were not interacting with intellectuals and others off campus, Boyer (1996) contends that the value of off-campus interaction is understanding and responding to society's problems. He advocates 
for higher education that engages with issues outside the "ivory tower," maintaining the need for community engagement to be institutionalized as an essential part of higher education.

More recently, critics (Butin, 2006; Furco, 2010; Hartley, Saltmarsh, and Clayton, 2010) questioned whether service-learning in the United States has fulfilled its transformative potential. According to Hartley et al. (2010), the momentum stalled and the ability of higher education to address societal challenges is again under scrutiny. While some students value engagement efforts like CSL as a method of transformative learning or enhancing social responsibility, others view CSL mostly as a means to explore employment opportunities and acquire job skills through hands-on experience (Gemmel and Clayton, 2009; Himley, 2004). These two perspectives need not be seen as incompatible; we argue that students can be transformed in CSL and also gain skills to improve their employability.

\section{Structure and funding}

Some national organizations and structures have funded and supported SL across postsecondary institutions in the United States. In 1985, a group of university presidents formed a national coalition called Campus Compact to promote community engagement through service programs in higher education (Butin, 2007a; Cameron, 2010; Flecky, 2011; Furco, 2010; Smith, 2010; Taylor et al., 2015; Ward, 2003). In 1995, roughly 250 institutions were involved in Campus Compact, and today the coalition reports that nearly 1,000 institutions (colleges and universities) are part of this network ("Who we are," n.d.). This rise in institutional support for SL, especially at the highest administrative levels, shows that civic and social responsibility continues to be valued in the U.S. higher education system. Significantly, while the national support structure for CSL in Canada, as we detail later, was founded and managed by individual faculty and staff, SL in the U.S. has seen consistent support from administration, which has led to its more uniform institutionalization across the nation.

A critical moment in the development of the field in the U.S. occurred in 1994, when the federal government passed the National and Community Service Trust Act. ${ }^{2}$ This Act made "funds available to higher education institutions to set up service-learning initiatives that encouraged students to engage in community service projects tied to academic learning objectives" (Furco, 2010, p. 377). Combined with Campus Compact, this Act and the subsequent establishment of the government granting program Learn and Serve America formed a national structure to fund and support SL initiatives (Flecky, 2011). Further support for SL was secured through partnerships between private foundations, such as the Kellogg Foundation, and national higher education organizations (Furco, 2010; Smith, 2010). Over a decade later, in 2009, federal funding for SL remained strong: "President Obama declared this period 'the new era of service' as he signed the Edward M. Kennedy Serve America Act, allocating over a billion dollars to service-learning" (Raddon and Harrison, 2015, p. 136). In recent years, however, funding of SL in the U.S. has changed. Post-secondary institutions are now often required "to match the [government] grant funds with institutional funds or other

\footnotetext{
${ }^{2}$ It is important to note that this came after the advocacy and practices of universities around SL.
} 
in-kind resources as the way to secure greater institutional investment in public engagement work" (Furco, 2010, p. 379). Furthermore, many federal- or state-level grants have ceased, requiring institutions to readjust service-learning activities and seek other sources of funding. ${ }^{3}$ Furco (2010) interprets the shift as a move away from dependence on federal funding and toward the institutional sustainability of SL, but it is also important to consider how this shift embodies a neoliberal agenda, in which government responsibilities are off-loaded onto the private or non-profit sector.

Indeed, the institutionalization of SL "across the majority of colleges and universities" in the U.S. (Butin, 2010, p. xiv) has been achieved not only through a legacy of strong federal funding and policy, but through related processes of "accreditation, classification, and ranking schemes" (Hollander, 2010, p. viii). In 2005, for example, the Carnegie Foundation for the Advancement of Teaching established an "elective classification for HE [higher education] institutions to be recognized as community engaged institutions" (Taylor et al., 2015, p. 8). This elective Community Engagement Classification system ${ }^{4}$ builds on Boyer's vision for higher education by identifying three elements of community engagement at postsecondary institutions: 1) curricular engagement; 2) outreach and partnerships; and 3) curricular engagement and outreach partnerships together. The benefits of this tool include its ability to track SL across campuses and to provide faculty with a renewed interest to make SL noticeable and sustainable in higher education (Flecky, 2011).

In addition to almost a half-century of government and post-secondary support for the field of service-learning, individual instructors, students, staff, and community partners are well-supported in SL curriculum and/or program design and delivery through the wealth of open-access resources available through the National Service Learning Clearinghouse, as well as a robust body of nation-specific research available through U.S. journals, including most notably the open-access Michigan Journal for Community Service Learning. In sum, SL in the U.S. is well-established, having moved from early concerns about legitimacy to ever-increasing visibility, institutionalization, and standardization across the country.

\section{Canadian CSL: Overview and Recommendations}

Keshen, Holland, and Moely (2010) argue that the roots of CSL in Canada "trace back to the late-nineteenth century, are as old as similar U.S. initiatives, and link to the intensification of social problems associated with the rise of urban-industrial society" (p. ix). But land-grant universities, like those to which the roots of SL in the U.S. are traced, were present only in Canada's western provinces (Smith, 2010, p. 5). Many Canadian universities of the time were affiliated with and financed by churches (Keshen et al., 2010, p. xi) and were informed

\footnotetext{
${ }^{3}$ In 2011, the government funding for Learn and Serve America (LSA) was removed. See Ryan (2012).

${ }^{4}$ The definition of community engagement from the Carnegie Foundation is the most widely used and cited in the existing discourse (Furco, 2010).
} 
by Christian principles of outreach and charity. ${ }^{5}$ They were also informed by "the rise of Progressivism and the modern social sciences," which promised "greater efficiency, order, and uplift, particularly to urban centres confronting growing social challenges” (p. ix). Influenced by service initiatives in Britain (such as the settlement movement), "Canadian university students were encouraged during this time to work with inner city church missions and organizations such as the Young Men's Christian Association” (p. xi).

While service and "engagement" thus have a long history in Canadian institutions, CSL as such originated in 1996 at St. Francis Xavier University (StFX) in Nova Scotia (Keshen et al., 2010, p. xii), a Catholic-affiliated institution with a long history of community engagement and economic development (p. xi). Located in the small, rural town of Antigonish, the program at StFX was initially organized by a single faculty member and has always had an explicit focus on social justice (Gelmon, Sherman, Gaudet, Mitchell, and Trotter, 2004, p. 205-206) rather than charity (an important distinction in CSL approaches, discussed later). In 1999, based on the strength of their existing work in CSL, StFX received five years of program development funding from the J.W. McConnell Family Foundation (p. 205).

The beginning of widespread institutionalization of CSL in Canada did not occur until 2005, when the McConnell Foundation provided seed funding to initiate CSL programs at ten universities across Canada and to help establish a national association, the Canadian Alliance for Community Service-Learning (Raddon and Harrison, 2015). ${ }^{6}$ As of 2010, CSL programs could be found at over fifty universities in Canada (approximately two thirds of the total), although most of these were five years old or less (Keshen et al., 2010). Taylor et al. (2015) note that overall, since 2000, "there has been significant growth of CSL within Canadian universities and colleges. But programs tend to be small in terms of staffing, resources, and student numbers" (p. 2).

As in the United States, CSL in Canada is driven by an interest in improving student experience (Fryer et al., 2007) and the "conviction that universities have a responsibility to make their research, teaching, and service more relevant to, and engaged with, important societal issues" (p. 7). In Canada, most post-secondary institutions are publicly funded, which may heighten this sense of accountability (p. 7). Canadian CSL has certainly learned from the evolution of SL in the United States, but as Smith (2010) states, it "cannot seem to be a direct import from America; it must show sensitivity to Canadian leaders' values

\footnotetext{
${ }^{5}$ Himley (2004) also traces the roots of SL in the United States to Christian outreach (particularly that of white women volunteers), but this does not appear to be as strong an explanatory narrative of SL's origins in the U.S. as is the land-grant tradition. In both national contexts, the linkage between Christianity and service-learning needs further research.

${ }^{6}$ Approximately $40 \%$ of the universities in Canada applied to the McConnell Foundation's call for proposals (Cameron, 2010, p. 12).

${ }^{7}$ Other scholars (Keshen et al.,2010) posit that it is perhaps because Canada's universities are largely funded by the government (with far fewer privately funded or faith-based institutions than in the U.S.) that Canada has been slower to take up CSL. In the U.S., private institutions are most involved in SL: "[a]ccording to a 2008 report from Campus Compact, 'Faith-based and historically black colleges and universities reported the highest levels of student service, with $61 \%$ of students participating in service and civic engagement"' (Keshen et al. 2010, p. xii). The reasons for this statistic requires further research, but one could speculate that the charity ethic of much Christianity and the struggle for civil rights in the black community have played a role in shaping the SL picture in the U.S..
} 
and social structures" (p. 1). While Smith does not elaborate on these values, Cawley (2007) from the McConnell Foundation proposes that they include respect for diversity, solidarity, environmental stewardship, and spirituality (p. 3). Fryer (2007) further explains that community service-learning in Canada is "grounded in [a] tradition of caring for each other, which...is related to factors such as our relatively harsh climate and our rural history... [w] have needed each other to survive" (p. 5). She cites the "strong social safety net" of the post-WWII era and "our publicly funded, universal health care system" as examples of this ethic of care (p. 5). Chambers (2009) echoes this idea, noting that "commitment to the social well-being of Canadian citizens and public institutions is viewed as a central value of the Canadian identity" (p. 94). Another perspective might be to consider that CSL emerged in Canada, post-1970s, at a time in which the political climate was largely showing support for social-democratic values, and so the ethic of care that Fryer (2007) and Chambers (2009) identify within Canadian CSL makes sense when situated within these political conditions.

While many Canadians embrace these values, it would be naïve to suggest that they characterize Canada in any uncomplicated fashion. As a settler colonial nation-state with a legacy of discriminatory and sometimes genocidal policies and practices, including Indian residential schools, the internment of Japanese-Canadians, the Chinese Head Tax, and the ongoing abrogation of treaties with Indigenous nations, to name a few, Canada, like the U.S., is hardly "caring" to all peoples within its borders. One need only consider the chronic underfunding of education for First Nations children on reserve, for example, to realize that Canada's commitment to social well-being does not extend equally or equitably to all. Therefore, even though CSL discourse in Canada "rarely invokes Canadian national identity" (Smith, 2010, p. 5), and never with the patriotic fervor of the States, preferring instead to focus on the "needs of local communities and global contexts" (p. 5), it is incumbent upon CSL practitioners and researchers in this country to examine critically the way in which "Canadian values" can obscure the very inequities that CSL claims to address.

\section{National CSL infrastructure and the Canadian Alliance for Community Service-Learning}

As Taylor and her colleagues (2015) emphasize, Canadian CSL "lacks the coordination evident in the US" (p. 9). In part, this is because Canada is a large country with a relatively small population, ${ }^{8}$ a factor that impedes "our ability to build momentum for CSL and community engagement" (Fryer et al., 2007, p. 17). As Fryer explains, even teleconference scheduling is a challenge across distance and time zones. "It is hard," she emphazises, "to create a critical mass of practitioners and researchers . . . to include the diversity of voices we would like to include" (Fryer et al., 2007, p. 18). Also, because Canada is an officially bilingual country, "with a long-standing Francophone separatist movement in Quebec," there is the additional challenge of building national momentum across linguistic and political differences (p. 17).

The Canadian Alliance for Community Service-Learning (CACSL), a national organization

\footnotetext{
${ }^{8}$ Canada is the second-largest country in the world, covering 3.85 million square miles, and has a population of roughly 33
} million (as of 2011). The U.S., which covers 3.8 million square miles, has a population of 310.5 million (as of 2011). 
for CSL in Canada, has worked to create this momentum, connecting key players in the field, assisting with CSL research, and creating linkages between organizations at national, provincial, and local levels. Although CACSL is currently inactive, ${ }^{9}$ its many contributions are recognized as foundational to CSL in Canada. Historically, it has played an integral role in archiving and distributing information about CSL programs, and it has guided CSL practitioners with various tools to support their involvement in CSL practice. CACSL's origins can be traced to 2001, when StFX invited CSL practitioners from across Canada to attend a three-day symposium on CSL in Canada (CACSL). Approximately ten people attended this initial meeting (Fryer et al., 2007, p. 11). Subsequent meetings were held in 2002 at the University of Guelph, where a national listserv was created; in 2003 at the University of British Columbia; and in 2004 at the University of Ottawa.

At the 2003 meeting in Vancouver, a national steering committee was formed "with specific goals to create a national association to promote and support CSL in Canada, especially through exploring funding opportunities for both individual campus CSL programs and the national association" (CACSL). ${ }^{10}$ From its inception onward, the steering committee was made up of a mix of faculty and university staff (e.g., curriculum development specialists, student support staff) and, later, community partner representatives (e.g., Volunteer Centre staff) (N. Van Styvendale, personal communication, March 10, 2017). ${ }^{11}$ This mix speaks to the deliberate democratization and grassroots approach of CSL in Canada and is distinct from the approach taken by national organizations in the U.S., such as Campus Compact or IARSLCE (International Association for Research in Service-Learning and Community Engagement), whose boards are composed mainly of faculty and university administrators.

As a national support structure, partnership broker, and resource hub, CACSL paralleled Campus Compact, although without the same structural effect or organizational reach of its southern counterpart. This is because CACSL did not benefit from the same level or stability of funding, something which the current status of the alliance ultimately speaks to. In 2004, the J.W. McConnell Foundation provided funds to establish the association, but CACSL relied on one staff member (who, from the end of McConnell funding in 2010, operated on a parttime and then volunteer basis) to coordinate networking and learning opportunities, whereas Campus Compact has a healthy cadre of national staff, as well as executive directors for offices in individual states.

Originally, the acronym CACSL stood for the Canadian Association for Community Service-Leaning; in 2007, the name was changed to the Canadian Alliance for Community Service-Learning to "more truly reflect a vision of a collaborative, supportive network of CSL colleagues and programs across Canada" (CACSL). The change also recognized that "association" was an inaccurate term, suggesting formal cohesion when the organization was

\footnotetext{
${ }^{9}$ See the introduction to this issue for more details. Despite its current inactivity, the CACSL website remains online, and there has been a call for new leadership for the alliance. Our paper emphasizes the need to support and fund CACSL as a vital, ongoing resource for the CSL movement in Canada.

${ }^{10}$ See Briggs, this issue, for more on the development of CACSL.

${ }^{11}$ See CACSL's website for a list of past steering committee members.
} 
more of an informal network. Over the years, CACSL played an important role in hosting an annual conference that provided unique networking opportunities to Canadian CSL scholars and practitioners. Information and records of past acheivements and events are still available through the CACSL website. The first conference, in 2012, was held at the University of Saskatchewan in Saskatoon ("Impacts of Community Engagement"), followed by the second, in 2014, at Algonquin College in Ottawa ("Healthy \& Resilient Communities"), and the third at Mount Royal University in Calgary ("Impact for Sustainability") in 2016. For the latter two, CACSL partnered with Volunteer Canada to co-host a conference and Volunteer Centre Leadership Forum, thus increasing community voice at the event and highlighting the national commitment to community. This national event for CSL and Community Engagement (CE) alternates with Community University (CU) Expo to connect CSL scholars conducting research and pedagogy on CSL/CE. Because of the focus on community partners and perspectives, the biennial conference and the annual CU Expo have a markedly different tone and agenda from the International Association for Research on Service-Learning and Community Engagement (IARSLCE) conference, a U.S.-based organization with an intensive research focus and largely university-based membership.

Canadian CSL will benefit from the foundation of networking and coordination provided by CACSL. Looking toward the future, we are hopeful that there will be renewed, active leadership for CACSL, and-perhaps as part of this renewal-we suggest an online network to advance Canadian scholarship on CSL. Similar to the graduate network in the U.S. (Graduate Student Network - GSN, an affiliate community of IARSLCE), an online network for Canadian scholars would provide a virtual community to advance CSL research and share promising practices. This virtual community would benefit from students and faculty, community partners/organizations, and other key players (administrators, coordinators, or evaluators of CSL programs within Canadian institutions) who are essential in providing consistent leadership for CSL; these perspectives are vital to critical conversations that shape the field (Gemmel and Clayton, 2009; Hayes, 2006). An online forum is particularly relevant in the Canadian context since the country is geographically large and universities are dispersed. Unlike the U.S., which has state and regional groups and events (e.g., Campus Compact has annual regional conferences), Canada has limited regional sub-groups or infrastructure due in part to its much smaller population. ${ }^{12}$

\section{Funding and Evaluation of CSL in Canada}

CSL programs in Canada have been funded mainly through foundations, the private sector, and provincial government allocations to postsecondary institutions (Taylor et al., 2015, p. 9). ${ }^{13}$ This funding model is different from that in the U.S., where, in addition to substantial private

\footnotetext{
12 Taylor et al. (2015) note the existence of an Ontario CSL Network, formed in 2009 and including approximately 24 universities and 8 colleges (p. 9). To our knowledge, no other regional networks exist.

${ }^{13}$ As of 2007, there were no specific funds allocated by provincial governments for CSL (Fryer, Wallis, Sattar, Annette, Battistoni, and Lund-Chaix, 2007, p. 11). This still appears to be the case. CSL is provincially funded in the sense that institutions are funded by the provinces and may choose to allocate funds to CSL programs.
} 
sector and foundation funding, the federal government has provided ongoing support through granting programs such as Learn and Serve America. Because Canada does not have a federal department or ministry of education, and "[u]nder Canada's constitutional division of powers, postsecondary or higher education is the responsibility of provincial governments" (Fryer, 2007, p. 11), national funding for CSL would be difficult to achieve. One exception would be funding through federal research grants, such as those provided by the Social Sciences and Humanities Research Council (SSHRC), which can support individual CSL research projects (Smith, 2010).

In the absence of government funding, CSL in Canada has been profoundly shaped by the support and interests of private foundations, most notably the J.W. McConnell Family Foundation, but also the Carthy Foundation and the Max Bell Foundation (Smith, 2010, p. 9). An emphasis on community impact has been necessary to secure support from these foundations, which "have been much more interested in social innovation, community participation, and community impact than the institutionalization of a program within a university's structure" (Smith, 2010, p. 9). In addition to funding the CSL program at StFX in 1999, the McConnell Foundation provided $\$ 9,500,000$ to support CSL at ten Canadian institutions between 2004 and 2011 (Cameron, 2010; CCED, n.d.; Smith, 2010; Taylor et al., 2015). This funding was motivated, as then-Senior Program Officer John Cawley (2007) observed, by the Foundation's interest in "capacity building for community organizations and in supporting the relationship between universities and the larger communities in which they are located" (p. 1). In CSL, the Foundation saw the opportunity to "raise fundamental questions about the relevancy of universities as we know them" through the "democratization of knowledge-in which many stakeholders with diverse backgrounds collaboratively engage in a process of sharing information and creating knowledge for use by communities" (Cawley, 2007, p. 3). The goal, as Keshen et al. (2010) summarize, was to "transform[ universities into community-builders" (p. xii). As the catalyst for widespread CSL in Canada, McConnell's stated focus on building community capacity and transforming the university is quite different from at least the initial motivations for SL in the United States, which focused more on disseminating the university's resources than transforming them. Despite the good intentions of these foundations, we recognize the need to contextualize their stated goals by acknowledging that these are private agents who may be working toward particular political and social goals of their own. Further, more work needs to be done to compare the mandates and practices of CSL private funders across the U.S. and Canada in order to explore how CSL is shaped by differing private agendas.

With the end of McConnell Foundation funding for CSL initiatives, programs in Canada face sustainability challenges into the future (Stack-Cutler and Dorow, 2009; Hayes, 2006). While CSL projects can often find internal institutional support-for example, through a university's teaching and learning fund-Butin (2006) cautions that funding through such "“soft' short term grants" contributes to the instability of SL in higher education (p. 474). Ultimately, if we want to see CSL expand in Canada, we need to strategize at both the national and local level about how best to attain sustainable, long-term funding. In considering future funding models, we should also consider the McConnell Foundation's retrospection that 
"[b]y making grants to the universities, the Foundation reinforced the power imbalance between the universities and community organizations. As a result, universities have tended to frame the placements around courses and allocate budgets to meet their needs" ("Key Lessons"). Given these concerns, one possibility would be to advocate for funding to support community organizations, rather than (only) postsecondary institutions, to develop the infrastructure needed for CSL programs or community-campus partnerships more generally. ${ }^{14}$

In terms of evaluation, implementing a classification system for CSL (such as that developed in the U.S. by the Carnegie Foundation) has possibilities, limitations, and risks. Fitzpatrick (2013) recommends a similar type of assessment for Canadian universities, to allow CSL to become more visible and sustainable here. Such a tool would strengthen accountability and consistency in how service activities are presented and practiced by institutions, ensuring that university mission statements align with actual engagement activities on campus. But any standardization poses risks and may elide the regional and relational differences that characterize CSL in Canada. There is also value, we suggest, in the more nuanced understandings of engagement that can be generated through stories and qualitative interviews with community partners, faculty, staff, and students. Recently, the SSHRC-funded national research collaboration CFICE (Community First: Impacts of Community Engagement) began to investigate the "co-creation of a community-first classification system for community-campus engagement (CCE) in the Canadian context" (Koller, 2017). Based on a review of international models of classification and preliminary discussions with those involved in the CCE movement in Canada, the team concluded that "it is more appropriate in the Canadian CCE movement to talk about 'culture change' in higher education, the process whereby an ethic of CCE might be authentically embedded in the practices of PSIs [post-secondary institutions], rather than 'institutionalization,' which implies a structural rather than a relational process" (Koller, 2017).

For culture change to occur, institutions must take engaged scholarship into account in the evaluation of faculty members for tenure and promotion. Canadian universities have "increasingly adopted the language of community engagement in their speeches and mission statements," but this messaging "has not yet been fully matched by a growth in institutional supports for community-engaged scholarship [which includes CSL], including professional recognition" (Barreno, Elliot, Madueke, and Sarny, 2013, p. 3). The McConnell Foundation likewise observes that "the current tenure, pay and promotion policies of universities for academics, in which research and publications are the main criteria inhibit the growth of effective CSL programs. Until community service is valued in the same way, many academics will be reluctant to commit the time necessary to effectively design and implement CSL programs" ("Key Lessons”). In 2010, the Community-Engaged Scholarship Partnership, a working group comprised of members from eight Canadian universities and supported by the international organization CCPH (Community Campus Partnerships for Health), examined the written policies of sixteen universities and three colleges, as well as conducted qualitative interviews with community-engaged scholars across Canada. Although CCPH found the

\footnotetext{
${ }^{14}$ See Briggs, this issue.
} 
standards of practice for community-engaged scholarship to be "fairly consistent across institutions" (Barreno et al., 2013, p. 74), this work was not always consistently recognized. One challenge is that "[c]ommunity-engaged scholars work primarily in the public sphere, [so] CES is often taken out of the research realm and placed in a realm of public service, voluntarism and community outreach" (Barreno et al., 2013, p. 74). CCPH developed a rubric for use by tenure and promotion committees (p. 81-83). The rubric identifies characteristics of community-engaged scholarship, such as clear and measurable community outcomes, and effective dissemination of knowledge to multiple audiences, which should be operationalized in locally specific ways to mesh with specific community and institutional contexts.

\section{CSL scholarship and theoretical models in Canada}

Experiences of CSL are documented across the country, with a historical timeline on the CACSL website, reports that scan the Canadian field, and compilations of Canadian CSL resources (Brown et al., 2007; Gemmel and Clayton, 2009; Hayes, 2006; Raykov, Taylor, and Yochim, 2015; Taylor et al., 2015). Much of this scholarship is recent, with around $60 \%$ of it published in the years since 2010 (Raykov et al., 2015, p. 1). Although there has been a recent surge of Canadian scholarship, Taylor et al. (2015) found that more than two thirds (69\%) of the 2,667 peer-reviewed service-learning studies listed in the ERIC database were conducted in the United States; only 4\% were Canadian (p. 12). There is a need to coordinate, synthesize, and share knowledge about CSL, perhaps through a web portal or hub, and to conduct further research and scholarly work on all aspects of CSL. With the 2015 launch of this very Engaged Scholar Journal, there is an opportunity to establish a central Canadian site for the publication of CSL research, which until now has been published mostly in U.S. journals (Raykov et al., 2015).

Taylor et al. (2015) provide a valuable review of existing SL/CSL literature in four common themes: CSL delivery and outcomes; student learning about civic engagement, social responsibility, and difference; diversity in the CSL classroom; and structures and supports for effective CSL. While this review does not focus only on Canadian sources, its analysis of scholarly trends highlights a continuum of interests that exists on both sides of the border. Taylor et al. (2015) emphasize that "literature related to Indigenous (First Nations, Inuit and Metis) students [is] particularly limited” (p. 23), a gap that exists in the U.S. scholarship as well, and is especially striking given the settler colonial history and ongoing policies and practices of both nations. In response to this gap, as well as the need for an intersectional approach to CSL research more generally, Taylor et al. (2015) call for specifically "Canadian studies exploring the ability of CSL to provide meaningful educational experiences for Indigenous, first generation, international and racialized and differently-abled students.... Research into the relationship between student positionality and experiences in communities is also needed" (p. 29). Given the current interest Canadian post-secondary institutions have shown in reconciliation between Indigenous and non-Indigenous peoples, as well as the country's continuing investment in the discourse of "multiculturalism," it is timely for Canadian scholars to pursue research that examines the role that CSL plays in promoting or critiquing these national projects.

In terms of research methodology, much current CSL/SL research is descriptive; it uses 
case studies or describes programs or courses (Taylor et al., 2015, p. 13). Specific methodologies are not often discussed; when they are, qualitative methods, interviews, and focus groups are more common than quantitative, mixed methods, participatory, or action research methods (p. 13). There is a need for research that uses these methods, as well as longitudinal studies, which are also lacking (p. 4). As Gemmel and Clayton (2009) argue, scholars need to capture how key constituencies (students, institutions, and communities) conceptualize the outcomes of CSL, specifically in Canada. The key is to collect information that "increases the institutional assessment of student learning outcomes and community impact of service-learning," rather than merely quantifying the number of service-learning courses and so forth (Bringle and Hatcher, 2009, p. 41). It is crucial that this scholarship include the perspectives of the community, which are still largely absent in the existing literature (Stoecker and Tryon, 2009).

Theoretical models to guide CSL in Canada are also needed, as few such models exist (Chambers, 2009). As in the U.S., CSL in this country is influenced conceptually by the educational theories of John Dewey, David Kolb, and Paulo Freire (Taylor et al., 2015, p. 2). Drawing on these scholars, Chambers (2009) summarizes the theoretical underpinnings of service-learning, providing four theories of learning (experiential education, social learning, student development, and liberatory education) to guide CSL approaches in Canada. Through these theories, he argues, we can understand "how learning occurs within a social context (experiential education and social learning), how student participants are impacted, personally and educationally, by their involvement in service-learning (student development), and how social change and social consciousness can occur through service-learning (liberatory education)" (p. 95).

In addition to these educational theories, CSL is informed by what Chambers (2009) calls three "touch points": the philanthropic approach, the social justice approach, and the social transformation approach. These approaches, which speak to the varied orientations and desired outcomes of CSL practices, echo the long-established distinction between "charity" and "social justice" models of CSL (Kahne and Westheimer, 1996; Morton, 1995), which are sometimes referred to as "traditional" and "critical" models (Mitchell, 2008). Put simply, the traditional or charity model "emphasiz[es] service without attention to systems of inequality" (Taylor et al., 2015, p. 16), whereas the critical or social justice model "aims to 'dismantle structures of injustice"' (Mitchell as cited in Taylor et al., 2015, p.16). It is important to remember, however, that "the realities of programming are more complex than these dichotomies suggest" (Taylor et al., 2015, p. 16); indeed, because CSL, by its very nature, is shaped by multiple people, perspectives, and conditions, any iteration of CSL may include a mix of charity and social justice approaches, or may align with neither. ${ }^{15}$ Prominent servicelearning scholar Dan Butin (2007b) takes a similar tack, proposing that there are four types of

\footnotetext{
${ }^{15}$ In considering how the charity versus social justice debate applies in a Canadian context, note that Canada's first CSL program was at StFX, an institution with a history of social justice work (see Kahlke and Taylor, this issue).
} 
SL (technical, cultural, political, and anti-foundational), ${ }^{16}$ but stressing that these approaches are not mutually exclusive; often, they overlap. Chambers (2009), like Butin, notes that his three touch points "serve as bridges, not walls. In other words, the touch points connect and overlap and are not seen as strict impenetrable cut-offs between approaches" (p. 85).

In sum, CSL models in Canada are not unique. Canadian scholarship builds on theories that are widely cited in the U.S. literature, and tends not to address, in-depth, how these theories specifically apply (or do not apply) in the Canadian context. Drawing and perhaps departing from existing models, Canadian scholars and practitioners have an opportunity to build CSL models specific to the Canadian or regional context. As Kahlke and Taylor argue in this issue, CSL in Canada is place-based, shaped by the community needs and institutional particularities of the places in which it is located-there are community-driven, issue-based programs (like the Food Security Research Network at Lakehead University), locale-specific initiatives (like the Trent Community Research Centre, located in downtown Peterborough), and theme-based social enterprises (like the Projet d'Intervention dans la Communauté at the Université du Québec à Trois-Rivières). Canadian theories and models of CSL should draw on and analyze these specificities.

\section{Conclusion}

Now over two decades old, CSL in Canada continues to grow and garner public attention in 2018. Funding opportunities at the beginning of the twenty-first century, particularly through the J.W. McConnell Family Foundation, generated many CSL activities that continue to exist across Canadian universities and communities. Also during this time, CACSL arose as a national hub that facilitated valuable connections between faculty, staff, students, and community members through CSL activities, resources, and events. In Canada, the field emerged not through the mandate of high-level administrators or the support of government, as it did in the U.S., but through the coming together of scholars and postsecondary staff, and the support of philanthropic foundations interested in "social innovation, community participation, and community impact" (Smith, 2010, p. 9).

Canadian CSL is distinct from SL in the U.S., which centres on nationalistic concerns about U.S. society, educational reforms, democracy, and the need to serve the country. As the U.S. continues to institutionalize service-learning, CSL in Canada focuses on partnerships with community to support initiatives across various disciplines and faculties. "Sustainability," as Smith (2010) argues, is still a key term in Canadian CSL discourse (p. 7). "Unlike the American movement," she continues, "higher education is not the central stage of the initiative. The frame or context is the whole community, and universities are only part of the community writ large" (p. 9). Even so, CSL here is strongly influenced by SL in the U.S., and much can be learned from what does and does not work there; some of the recommendations in this

\footnotetext{
${ }^{16}$ Butin's “'technical' conception focuses on the pedagogical effectiveness of CSL; a 'cultural' conceptualization considers the meanings of the practice for the individuals and institutions involved; and the 'political' conceptualization aims to empower historically marginalized groups in society. Finally, an 'anti-foundational' approach aims to foster a state of doubt in students as a prerequisite for thoughtful deliberation" (Taylor et al., 2015, p. 11).
} 
paper-for example, the idea to create a similar Graduate Student Network, but to adapt it to engage all stakeholders involved in CSL_came from reflecting on the work done in the U.S.

Nearly a decade ago, John Cawley from the McConnell Foundation acknowledged the deep roots that CSL had on campuses and in communities across Canada. Today, strategic conversations need to take place about the shape of CSL across the country and the obstacles that exist, particularly around funding and national strategy, to ensure that CSL continues to be mutually beneficial to communities and postsecondary institutions, that it is delivered effectively, and that its outcomes for all stakeholders are documented. As scholars such as Hayes (2006) and Taylor et al. (2015) maintain, now is the time to strengthen a coordinated approach with specific attention to Canadian research and practice, and, we argue, with CACSL adequately resourced and staffed as a national coordinating body. ${ }^{17}$ Our findings highlight the value of building a culture of engagement through sustainable infrastructure that invites and enables a continuous cycle of learning with and in the community. Future action could include establishing a central location for the combined body of knowledge to support and critique CSL in the Canadian context, sharing resources, and interviewing founders of CSL in Canada to gather their insights. This coordination on a national scale will continue to advance the field.

Our exploration has focused on how the mandates and policies of private foundations have shaped the relational pieces of community service-learning in the Canadian context. Consistent with these findings, our proposed approach to CSL as community-engaged learning and research draws on the strengths of relationships with community partners, Canadian CSL history, and Canadian researchers' contributions. We advocate for a "community first" approach to CSL which strengthens sustainable partnerships to support civic engagement at the institutional and community level.

\section{About the Authors}

Wendy Aujla (corresponding author) is a Doctoral Candidate in sociology at the University of Alberta. She served, as an advisory board member, on the Community Service-Learning Program at the U of A (2012-2016). Wendy's teaching and research interests include community, gender, race, ethnicity, and family with specific attention to violence against women. Email: waujla@ualberta.ca

Zane Hamm has a $\mathrm{PhD}$ in Educational Policy Studies from the University of Alberta, specializing in Adult Education. Zane teaches CSL and an MBA program in Community Economic Development. She works with education, leadership, and community engagement in Canada, and internationally. Zane holds an MEd in International/Global Education.

${ }^{17}$ Ways to staff and provide resources for CACSL will have to be explored, but some possibilities include SSHRC, the McConnell Foundation, and the Pierre Elliot Trudeau Foundation. See: http://www.trudeaufoundation.ca/en. 


\section{References}

Barreno, L., Elliott, P. W., Madueke, I., \& Sarny, D. (2013). Community engaged scholarship and faculty assessment: A review of Canadian practices.

Boyer, E. (1996). The scholarship of engagement. Journal of Public Outreach, 1(1), 11-20.

Bringle, R. G., \& Hatcher, J. A. (2009). Innovative practices in service-learning and curricular engagement. New Directions for Higher Education, 147, 37-46.

Bringle, R. \& Hatcher, J. (1996). Implementing service-learning in higher education. Journal of Higher Education, 67(2), 221-239.

Butin, D. W. (2010). The futures of service-learning. In D. W. Butin (Ed.), Service learning in theory and practice: The future of community engagement in higher education (pp. 107-121). New York, NY: Palgrave Macmillan.

Butin, D. W. (2006). The limits of service-learning in higher education. The Review of Higher Education, 29 (4), 473-498.

Butin, D. W. (2007a). Focusing our aim: Strengthening faculty commitment to community engagement. Change, 39(6), 34-39.

Butin, D. W. (2007b). Justice-learning: Service-learning as justice-oriented education. Equity and Excellence in Education, 40(2), 177-183.

Brown, S. D., Meinhard, A., Ellis-Hale, K., Henderson, A. \& Foster, M. (2007). Community Service and Service Learning in Canada: A Profile of Programming across the Country.

Cameron, S. D. (2010). Getting wisdom: The transformative power of community service-learning. Montreal, QC: The J.W. McConnell Family Foundation.

CACSL. (n.d.). History of CACSL.

Campus Compact. (n.d.). Who we are. Retrieved from http://compact.org/who-we-are/

Cawley, J. (2007). Community service-learning: Reflections from the Foundation.

CCED. (n.d.). Learning in and for community: A Discussion Paper.

Chambers, T. (2009). A continuum of approaches to service-learning within

Canadian post-secondary education. Canadian Journal of Higher Education, 39 (2), 77-100.

Fitzpatrick, J. (2013, May 31). Nothing about us, without us: How the new credo for community engaged research is making a difference both in communities and at universities. University Affairs.

Flecky, K. (2011). Foundations of service learning. In K. Flecky \& L. Gitlow (Eds.), Service-learning in occupational therapy education: Philosophy and practice (pp. 1-18). Boston, MA: Jones and Bartlett.

Fryer, M. (n.d.). The call.

Fryer, M., Wallis, R., Sattar, K., Annette, J., Battistoni, R., \& Lund-Chaix, A. (2007). Context and culture: Models of engagement around the world. In S. Gelmon and S. Billig (Eds.), From passion to objectivity: International and cross-disciplinary perspectives on service-learning research (pp. 3-20). Charlotte, NC: Information Age Publishing.

Furco, A. (2010). The engaged campus: Toward a comprehensive approach to public engagement. British Journal of Educational Studies, 58(4), 375-390.

Gelmon, S., Sherman, A., Gaudet, M., Mitchell, C., \& Trotter, K. (2004). Institutionalizing servicelearning across the university: International comparisons. In M. Welch and S. Billig (Eds.), New perspectives in service-learning: Research to advance the field (pp. 195-217). Charlotte, NC: Information Age Publishing. 
Gemmel, L. J., \& Clayton, P. H. (2009). A comprehensive framework for community service-learning in Canada.

Giles, D. (2008). Understanding an emerging field of scholarship: Toward a research agenda for public, engaged scholarship. Journal of Higher Education Outreach and Engagement, 12(2), 97-106.

Hartley, M., Saltmarsh, J., \& Clayton, P. H. (2010). Is the civic engagement movement changing in higher education? British Journal of Educational Studies, 58(4), 391-406.

Hayes, E. (2006). Community service-learning in Canada: A scan of the field.

Himley, M. (2004). Facing (up to) "the stranger" in community service learning. College Composition and Communication, 55(3), 416-438.

Hoppe, L. S. (2004). A synthesis of the theoretical stances. In B. Speck and S. Hoppe (Eds.), Servicelearning: History, theory, and issues (pp. 137-150). Westport, CT: Praeger.

J. W. McConnell Foundation. Key lessons.

Kahne, J., \& Westheimer, J. (1996). In the service of what? The politics of service learning. Phi Delta Kappan, 7(9), 593-599.

Kendall, J. (1990). Combining service and learning: An introduction. In J. Kendall and Associates (Eds.), Combining service and learning: A resource book for community and public service (Vol. 1) (pp. 1-33). Raleigh, NC: National Society for Internships and Experiential Education.

Keshen, J., Holland, B. A., \& Moely, B. E. (2010). Introduction. In J. Keshen, B. A. Holland, \& B. E. Moely (Eds.), Research for what? Making engaged scholarship matter (pp. ix-xviii). Charlotte, NC: Information Age Publishing.

Koller, K. (2017, March 3). Creating a community first classification system for CCE.

Lena, H. F. (1995). How can Sociology contribute to integrating service learning in academic curricula? The American Sociologist, 4, 107-117.

Putnam, R. (1995). Bowling alone: America's declining social capital. Journal of Democracy 6(1), 65-78.

Mitchell, T. D. (2008). Traditional vs. critical service-learning: Engaging the literature to differentiate two models. Michigan Journal of Community Service Learning, 14(2), 50-65.

Mooney, L. A., \& Edwards, B. (2001). Experiential learning in sociology: Service learning and other community-based learning initiatives. Teaching Sociology, 29(2), 181-194.

Morton, K. (1995). The irony of service: Charity, project, and social change in service learning. The Michigan Journal of Community Service Learning, 2(1), 19-32.

Raddon, M. B., \& Harrison, B. (2015). Is service-learning the kind face of the neo-liberal university? Canadian Journal of Higher Education, 45(2), 134-153.

Raykov, M., Taylor, A., and Yochim, L. (2015). Community service-learning resource based Canadian CSL studies.

Ryan, M. (2012). Service-learning after Learn and Serve America: How five states are moving forward. Retrieved from http://www.ecs.org/clearinghouse/01/02/87/10287.pdf

Saltmarsh, J. (1996). Education for critical citizenship: John Dewey's contribution to The pedagogy of community service learning. Michigan Journal of Community Service learning, 3(1), 13-21.

Serino, C, Marciano, D., Scardigno, A. F., \& Manuti, A. (2012, August 13). How communities can react to crisis: Social capital as a source of empowerment and well-being. Global Journal of Community Psychology Practice, 3(3).

Sigmon, R. L. (1994). Linking Service with Learning in Liberal Arts Education. Washington,DC: Council of Independent Colleges.

Smith, T. S. (2010). Rhetorical strategies of the postsecondary community service movement in Canada. Partnerships: A Journal of Service-Learning \& Civic Engagement, 1(2), 1-18.

Engaged Scholar Journal: Community-Engaged Research, Teaching, and Learning 
Stack-Cutler, H., \& Dorow, S. (2009). "For the public good...": Report on community-university engaged learning. The Network for Community-Engaged Learning, Edmonton, AB: University of Alberta.

Stoecker, R., \& Tryon, E. A. (2009). Unheard voices. In R. Stoecker \& E. A. Tryon (Eds.), The unheard voices: Community organizations and service learning (pp. 1-18). Philadelphia, PA: Temple University Press.

Taylor, A., Butterwick, S., Raykov, M., Glick, S., Peikazadi, N., \& Mehrabi, S. (2015). Community servicelearning in Canadian bigher education.

Ward, K. A. (2003). Faculty service roles and the scholarship of engagement. ASHE- ERIC Higher Education Report, 29(5). San Francisco, CA: Jossey-Bass. 